\title{
Blueberry and honey vinegar: successive batch production, antioxidant potential and antimicrobial ability
}

\author{
Vinagre de mirtilo e mel: produção por bateladas sucessivas, potencial antioxidante \\ e habilidade antimicrobiana
}

\author{
Michel da Silva Fonseca', Vidiany Aparecida Queiroz Santos ${ }^{1}$, Gabrielle Cristina Calegari',

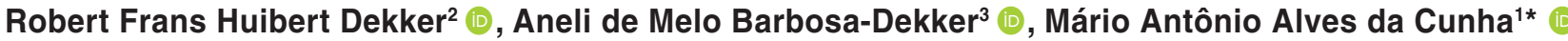 \\ 1 Universidade Tecnológica Federal do Paraná (UTFPR), Departamento de Química, Pato Branco/PR - Brasil \\ 2 Universidade Tecnológica Federal do Paraná (UTFPR), Programa de Pós-graduação em Engenharia Ambiental, Londrina/PR - Brasil \\ ${ }^{3}$ Universidade Estadual de Londrina (UEL), Departamento de Química, Londrina/PR - Brasil
}

\section{*Corresponding Author}

Mário Antônio Alves da Cunha, Universidade Tecnológica Federal do Paraná (UTFPR), Departamento de Química, Via do Conhecimento, km 01, CEP: 85503-390, Pato Branco/PR - Brasil, e-mail: mcunha@utfpr.edu.br

Cite as: Blueberry and honey vinegar: successive batch production, antioxidant potential and antimicrobial ability. Braz. J. Food Technol., v. 21, e2017101, 2018

Received: July 10, 2017; Accepted: Apr. 30, 2018

\section{Abstract}

Gourmet vinegars are versatile culinary ingredients that have aroused the interest of consumers not only for their unusual taste, but also for their health benefits. In this work, blueberry and honey wine was first obtained using a bench-scale bioreactor. This wine had high concentrations of phenolic compounds (706.18 mg GAE/mL) and appreciable free radical scavenging ability against DPPH ( $161.42 \mu \mathrm{mol}$ trolox equivalent/100 mL) and ABTS ${ }^{*+}(356.41 \mu \mathrm{mol}$ trolox equivalent/100 mL), as well as ferric-ion reducing antioxidant capacity $(1419.86 \mu \mathrm{mol} \mathrm{FeSO} / 100 \mathrm{~mL})$. In sequence, vinegar was produced from the wine in wooden barrels using successive acetification cycles. The average acetic acid concentration found in the vinegars was $4.4 \mathrm{~g} / 100 \mathrm{~mL}$, and the average acetic acid yield and volumetric productivity were $52.69 \%$ and $0.38 \mathrm{~g} /(\mathrm{L} . \mathrm{h})$, respectively. Appreciable polyphenolic compounds ( 681.87 to $847.98 \mu \mathrm{g} \mathrm{GAE} / \mathrm{mL}$ ) and anthocyanin (12.8 to $15.39 \mathrm{mg} / \mathrm{L}$ ) contents were found and high antioxidant activity. In addition, the vinegars demonstrated antimicrobial ability against Bacillus subtilis and Salmonella enterica Typhimurium.

Keywords: Acetic oxidation; Berries; Functional food; Wine.

\section{Resumo}

Vinagres gourmet são ingredientes culinários versáteis, que despertam o interesse dos consumidores não só pelo sabor peculiar, mas também pelos benefícios à saúde. Neste trabalho, inicialmente vinho de mirtilo e mel foi obtido em biorreator com altas concentrações de fenólicos (706,18 mg GAE/mL). Elevada capacidade de eliminação dos radicais livres $\operatorname{DPPH}\left(161,42 \mu \mathrm{mol}\right.$ de equivalente trolox/100 mL) e ABTS ${ }^{*+}(356,41 \mu \mathrm{mol}$ de equivalente trolox/100 mL), bem como capacidade antioxidante redutora de íons férricos $(1419,86 \mu \mathrm{mol} \mathrm{FeSO} / 100 \mathrm{~mL})$ também foram verificadas. Vinagre foi obtido a partir do vinho, em sucessivos ciclos de acetificação em barril de madeira. A concentração média de ácido acético encontrada foi de 4,4 g/100 mL e a produção média e a produtividade foram, respectivamente, 52,69\% e 0,38 g/L.h. Apreciáveis conteúdos de polifenóis (681,87 a 847,98 $\mu \mathrm{g} \mathrm{GAE} / \mathrm{mL}$ ), antocianinas (12,8 a 15,39 mg/L) e alta atividade antioxidante foram verificadas no vinagre. Os vinagres demonstraram capacidade antimicrobiana contra Bacillus subtilis e Salmonella enterica Typhimurium.

Palavras-chave: Alimentos funcionais; Pequenos frutos; Oxidação acética; Vinho. 


\section{Introduction}

The blueberry (Vaccinium ashei L.) is a native fruit from North America and Eurasia that belongs to the family Ericaceae and the small fruits group such as mulberry and physalis. Blueberries have been cultivated all over the world, especially in temperate climate countries, and have an acid-sweet or acidic taste and can be consumed both in natura and in processed forms (SHI et al., 2017).

The United States of America is the world's largest producer of blueberries, with more than 260,000 MT produced in 2014. Canada occupies the second position, producing about 182,000 MT in 2014 (FAO, 2014). On the other hand, blueberries are still little known in Brazil, but the country has the potential to produce them, especially in the southeastern and southern regions. The southern region of Brazil has the best cultivation characteristics, such as the appropriate climate and soil types, which has made this region the country's largest blueberry producer since cultivation began in 1980 (RODRIGUES et al., 2011).

The commercial exploitation of the blueberry is directly related to its functional characteristics, which include high levels of phenolic compounds and anthocyanins, vitamins $A, B, C$ and $K$, and minerals essential for human nutrition, such as phosphorus, manganese, iron, calcium, potassium and magnesium, in addition to having low levels of lipids and sodium (WANG et al., 2017). Its bioactive properties include being anticarcinogenic, anti-inflammatory, antihypertensive, hypoglycemic and showing a lipid-lowering potential, as well as having a high antioxidant capacity (DIACONEASA et al., 2015).

Considering these functional characteristics and the fact that the blueberry is a very perishable fruit, its use as a raw material in the production of high value-added products such as gourmet type vinegars could be an enterprising strategy. Vinegar is the oldest preservative of vegetables, meat and fish, and is produced from raw materials containing sugar or starch via sequential ethanol and acetic acid fermentations ( $\mathrm{HO}$ et al., 2016; TRCEK et al., 2016). It is used in a variety of food applications, including mayonnaise, salad dressings, sauces, ketchup, mustard and other food condiments (CUNHA et al., 2016).

An increase in demand for fruit-based vinegars has occurred recently, concurrently with documentation of the health benefits of vinegar itself. The functional therapeutic properties of vinegar include antibacterial activity, blood pressure reduction, antioxidant activity, reduction in the effects of diabetes, prevention of cardiovascular disease and increased vigor after exercise (BUDAK et al., 2014).

Thus the objective of the present work was to produce blueberry vinegars with added Apis mellifera honey in Grapia (Brazilian gold wood) barrels. The physicochemical parameters, total phenolic compound content, anthocyanins and antioxidant potential were evaluated in the blueberry fruit and in the blueberry and honey wine and vinegar. The antimicrobial ability of the blueberry vinegar was also assessed.

\section{Material and methods}

\subsection{Raw material and extraction of bioactive compounds}

Organic Rabbiteye variety blueberries were provided by a small fruit farm located in the city of Palmas, Paraná, Brazil (Latitude: $26^{\circ} 22^{\prime}$ 43.30" S and Longitude: 52 $7^{\prime}$ 19.50" W). Multifloral honey (Apis mellifera L.) was purchased from the local grocer in the city of Pato Branco, Paraná, Brazil, and used in the preparation of a blueberry pulp and honey based must for the alcoholic fermentation.

Eighty percent ( $80 \% \mathrm{v} / \mathrm{v})$ aqueous solutions of acetone, ethanol and methanol were evaluated as extracting agents of the phenolic and antioxidant compounds (CUNHA et al., 2016). Mature blueberry fruits were ground in a blender, frozen at $-50{ }^{\circ} \mathrm{C}$ and then freeze-dried. The extractions were carried out in Erlenmeyer flasks using the proportion of $2 \mathrm{~g}$ of disintegrated and freeze-dried fruits to $25 \mathrm{~mL}$ of extractive solutions. The flasks were shaken at $150 \mathrm{rpm}$ for $30 \mathrm{~min}$ at $30^{\circ} \mathrm{C}$ in a rotatory shaker, and the extracts then separated from the pulp and skins by filtering (filter paper) and used in the analyses for total phenolic compounds, anthocyanins and antioxidant activity.

\subsection{Microorganisms and inoculum preparation}

A commercial strain of Saccharomyces cerevisiaef. $r$. bayanus (Fermol Perlage, AEB Biochemistry Latin American SA, Brazil) was cultivated for $24 \mathrm{~h}$ at $28^{\circ} \mathrm{C}$ in malt-extract medium (20 g/L malt extract, $1 \mathrm{~g} / \mathrm{L}$ peptone and $20 \mathrm{~g} / \mathrm{L}$ glucose) with shaking at $120 \mathrm{rpm}$.

The yeast cells were recovered by centrifugation (1350 $\times \mathrm{g} / 30 \mathrm{~min}$ ) and re-suspended in an isotonic saline solution $(0.9 \% \mathrm{w} / \mathrm{v})$ to obtain a cell suspension with a standardized concentration. A standardized pre-inoculum containing $2 \times 10^{6}$ cells $/ \mathrm{mL}$ was employed in the alcoholic fermentation process.

The acetic acid bacteria employed in the acetification process were isolated from colonial red grape (Vitis labrusca) vinegar produced in the southwestern region of Paraná, Brazil. The acetic acid bacteria were isolated by cultivating non-pasteurized vinegar in GY medium (100 g/L glucose, $10 \mathrm{~g} / \mathrm{L}$ yeast extract and $100 \mathrm{mg} / \mathrm{L}$ natamycin) according to Cunha et al. (2016).

The inoculum was prepared in $500 \mathrm{~mL}$ Erlenmeyer flasks by mixing the acetic bacterial culture $(25 \mathrm{~mL})$ with blueberry wine $(155 \mathrm{~mL})$. The flasks were incubated at $30{ }^{\circ} \mathrm{C}$ for $24 \mathrm{~h}$ in an orbital shaker rotating at $120 \mathrm{rpm}$ for growth and cell adaptation, and then used in the acetic oxidation step. 


\subsection{Alcoholic fermentation and acetic oxidation}

The blueberry fruits were slowly thawed, pulped in a blender and then filtered through morim (cheese) cloth to remove the seeds and husks. The alcoholic fermentation must was prepared by blending the blueberry pulp with the amount of bee's honey required to obtain a fermentation broth with a standardized total soluble solids content of $16^{\circ}$ Brix. A commercial mineral salts blend (30 g/L; ENOVIT ${ }^{\circledR}$, Pascal Biotech, France) was used to supplement the must, which presented an initial pH of 3.26.

The pre-inoculum of $S$. cerevisiae $\left(30 \mathrm{~mL}, 2 \times 10^{6} \mathrm{cells} / \mathrm{mL}\right)$ was transferred to a $4 \mathrm{~L}$ fermentation vessel containing $270 \mathrm{~mL}$ of must and cultivated in a bench-scale bioreactor (Biostat B, B. Braun Melsungen, Germany) for $24 \mathrm{~h}$ at 28 ${ }^{\circ} \mathrm{C}$. Alcoholic fermentation was initiated by the addition of $2.7 \mathrm{~L}$ of fresh must to the bioreactor containing the adapted inoculum and carried out at $28^{\circ} \mathrm{C}$. The alcoholic fermentation was accompanied by evaluating the total soluble solids and total reducing sugars contents and verifying the amount of $\mathrm{CO}_{2}$ released. At the end of the fermentation run, the following parameters were determined: substrate consumption $\left(Y_{C}\right.$, percentage of total sugar content reduced), ethanol yield ( $Y_{P / S}$, calculated as the quantity of ethanol produced from the substrate consumed), volumetric productivity in terms of ethanol $\left(Q_{p}\right.$, calculated as the relationship between the maximum ethanol concentration and the fermentation time), alcoholic fermentation efficiency ( $\eta$, calculated as the relationship between the maximum theoretical yield in ethanol and the yield observed).

The blueberry and honey wine produced was recovered by centrifugation (1500 x g/30 min), supplemented with Acetozym ${ }^{\circledR}$ (Heinrich Frings GmbH \&AMP; Co, USA), and $1360 \mathrm{~mL}$ transferred to the Grapia barrel, which was inoculated with $140 \mathrm{~mL}$ of acetic acid bacteria culture. The total working volume was $1500 \mathrm{~mL}$ and the temperature was set at $28^{\circ} \mathrm{C}$. Wine acetification was accompanied by the determination of $\mathrm{pH}$ and acidity (expressed as acetic acid).

Three successive acetification cycles were carried out with the substitution of $65 \%$ of the vinegar with wine at the end of the first and second cycles. The yield in acetic acid was calculated based on the stoichiometric balance that $1 \mathrm{~g}$ of ethanol yields $1.304 \mathrm{~g}$ of acetic acid.

\subsection{Physicochemical characterization and determination of the bioactivity parameters}

The blueberry fruits were characterized with respect to their contents of lipids (soxhlet extraction method), crude protein (Kjeldahl method), mineral residue (incineration at $550{ }^{\circ} \mathrm{C}$ ), dietary fibre, moisture (kiln-drying method at $105^{\circ} \mathrm{C}$ ) and total soluble solids (hand refractometer), and also their $\mathrm{pH}$ values and titratable acidity (titrimetric method) (HORWITZ, 2016). The total reducing sugars were determined by the DNS method after hydrolysis with $1 \mathrm{~mol} / \mathrm{L} \mathrm{HCl}$ (MILLER, 1959), the total phenolic compounds by the Folin-Ciocalteau spectrophotometric method (SINGLETON et al., 1999), the total anthocyanins by a $\mathrm{pH}$ differential method (WANG; XU, 2007), and the antioxidant activity by 3 procedures: the DPPH method (BRAND-WILLLIAMS et al., 1995), the ABTS ${ }^{\bullet+}$ cation-radical discoloration assay (BUDAK; GUZEL-SEYDIM, 2010) and the FRAP method (RUFINO et al., 2010).

The wine and vinegars were analysed for $\mathrm{pH}$, titratable acidity, total soluble solids, total reducing sugars (DNS method), and the total phenolic compounds, anthocyanins and antioxidant activity.

The antimicrobial activity was assessed using the disc-diffusion method according to $\operatorname{CLSI}(2003,2008)$. The vinegar samples with concentrations of $4.2 \%$ ( $1^{\text {st }}$ cycle) and $4.8 \%\left(^{\text {nd }}\right.$ and $3^{\text {rd }}$ cycles) were evaluated against Gram-positive bacterial strains (Staphylococcus aureus ATCC 25923 and Bacillus subtilis ATCC 19659), Gram-negative strains (Salmonella enterica Typhimurium ATCC 0028 and Escherichia coli ATCC 25922) and yeasts (Candida tropicalis ATCC 13803 and Candida albicans ATCC 118804). The bacterial and yeast strains were cultured in Mueller-Hinton and Sabouraud broths, respectively, and the cell concentrations were then standardized according to the 0.5 MacFarland scale ( $\left.\cong 1.5 \times 10^{8} \mathrm{CFU} / \mathrm{mL}\right)$. A volume of $100 \mu \mathrm{L}$ of standardized concentration cell suspension was inoculated by spread-plating on Petri dishes containing Mueller-Hinton or Sabouroud agar. Paper disks (5 mm) were then impregnated $(10 \mu \mathrm{L})$ with the vinegar samples and distributed onto the surfaces of the Petri dishes. Tetracycline and fluconazole at concentrations of $30 \mu \mathrm{g} / \mathrm{mL}$ were used as the positive controls for bacteria and fungi, respectively, and a $0.9 \%$ saline solution was used as the negative control. The Petri dishes were incubated at $37^{\circ} \mathrm{C}$ for $24 \mathrm{~h}$ (bacteria) or $27^{\circ} \mathrm{C}$ for $72 \mathrm{~h}$ (yeasts), the diameters of the inhibition zones measured with a digital pachymeter and the results expressed in $\mathrm{mm}$.

\subsection{Statistical analysis}

The data was statistically analysed using the software STATISTIC 8.0, the data submitted to an analysis of variance and the means compared using the Tukey test at $5 \%$ significance.

\section{Results and discussion}

\subsection{Physicochemical quality parameters of the blueberry fruits}

Table 1 shows a moisture content of $78.33 \mathrm{~g} / 100 \mathrm{~g}$ for the fruits, similar to the value reported in the (NDB $\mathrm{N}^{\circ}$. 09052) USDA database $(76.78 \mathrm{~g} / 100 \mathrm{~g})$ as a reference value for blueberries (USDA, 2016). 
Blueberry and honey vinegar: successive batch production, antioxidant potential and antimicrobial ability

Fonseca, M. S. et al.

Table 1. Physicochemical quality parameters of blueberry fruits.

\begin{tabular}{|c|c|c|c|}
\hline \multicolumn{2}{|c|}{ Physicochemical parameters } & \multicolumn{2}{|c|}{ Values obtained } \\
\hline Moisture (g/100 g) & & \multicolumn{2}{|c|}{$78.33 \pm 0.18$} \\
\hline Aw & & \multicolumn{2}{|c|}{$0.96 \pm 0.01$} \\
\hline $\mathrm{pH}$ & & \multicolumn{2}{|c|}{$3.37 \pm 0.03$} \\
\hline Acidity (g citric acid/100 g) & & \multicolumn{2}{|c|}{$2.04 \pm 0.02$} \\
\hline Protein $(\mathrm{g} / 100 \mathrm{~g})$ & & \multicolumn{2}{|c|}{$1.70 \pm 0.06$} \\
\hline Lipids (g/100 g) & & \multicolumn{2}{|c|}{$0.14 \pm 0.01$} \\
\hline Mineral residue (g/100 g) & & \multicolumn{2}{|c|}{$1.24 \pm 0.02$} \\
\hline Diet fibre (g/100 g) & & \multicolumn{2}{|c|}{$8.21 \pm 0.01$} \\
\hline Total soluble solids ( ${ }^{\circ}$ Brix) & & \multicolumn{2}{|c|}{$12.20 \pm 0.46$} \\
\hline \multirow[t]{3}{*}{ TSS/TA ratio } & & \multicolumn{2}{|c|}{7.94} \\
\hline & \multicolumn{3}{|c|}{ Extracting solvent } \\
\hline & Acetone & Ethanol & Methanol \\
\hline Total phenolic compounds (mg GAE/100 g) & $1,117.84 \pm 0.19^{a}$ & $697.49 \pm 0.36^{c}$ & $1,004.2 \pm 0.18^{b}$ \\
\hline Anthocyanins (cyanidin-3-glucoside mg/100 g) & $113.64 \pm 0.97^{a}$ & $88.29 \pm 0.76^{c}$ & $97.54 \pm 0.18^{b}$ \\
\hline $\mathrm{ABTS}^{\bullet+}(\mu \mathrm{mol} \mathrm{TE} / \mathrm{g})^{*}$ & $156.08 \pm 30.01^{a}$ & $159.42 \pm 17.6^{\mathrm{a}}$ & $192.77 \pm 0.00^{\mathrm{a}}$ \\
\hline DPPH $(\mu \mathrm{mol} \mathrm{TE} / \mathrm{g})^{\star *}$ & $48.45 \pm 0.64^{\mathrm{a}}$ & $44.78 \pm 0.70^{a}$ & $49.93 \pm 6.40^{a}$ \\
\hline FRAP $\left(\mu \mathrm{mol} \mathrm{FeSO}{ }_{4} / g\right)^{\#}$ & $1,357.88 \pm 11.44^{a}$ & $879.09 \pm 17.6^{c}$ & $1,054.85 \pm 11.25^{b}$ \\
\hline
\end{tabular}

a,b,c Different letters in the same line are significantly different to each other $(p<0.05)$; Aw: water activity; $\mathrm{pH}$ : potential of hydrogen; TSS: total soluble solids; TA: titratable acidity; GAE: gallic acid equivalent; ABTS ${ }^{*+}$ and DPPH: total antioxidant capacity equivalent to Trolox by the "ABTS*+ and "DPPH methods; "FRAP: ferric reducing antioxidant power.

The results for $\mathrm{pH}(3.37)$ and $(\mathrm{TA})$ titratable acidity (expressed as grams of citric acid per $100 \mathrm{~g}$ of fruit $-2.04 \mathrm{~g} / 100 \mathrm{~g}$ ) indicated the fruits were quite acidic. Similar values for $\mathrm{pH}$ (3.64) and acidity (2.56 g citric acid/100 g) were reported by Souza et al. (2014) for blueberries grown in São Paulo state, Brazil, but blueberries cultivated in Turkey were less acid, with values ranging from 1.58 to $1.67 \mathrm{~g}$ of citric acid/100 g (COLAK et al., 2016). Likewise, mature blueberries cultivated in Nova Scotia (Canada) were much less acid than the Brazilian blueberries used in this work (GIBSON et al. 2013).

In relation to the protein content, higher values $(1.7 \mathrm{~g} / 100 \mathrm{~g})$ were found in the sample analysed in the present study, when compared with those described by Souza et al. (2014) $(0.48 \mathrm{~g} / 100 \mathrm{~g})$. The lipid content $(0.14 \mathrm{~g} / 100 \mathrm{~g})$ was similar to that described by these authors, who reported a value of $0.19 \mathrm{~g} / 100 \mathrm{~g}$, but they found a lower mineral residue content $(0.08 \mathrm{~g} / 100 \mathrm{~g})$. Reque et al. (2014) reported values for the mineral residue of $1.80 \mathrm{~g} / 100 \mathrm{~g}$, closer to those found in the present work $(1.24 \mathrm{~g} / 100 \mathrm{~g})$.

A high fibre content $(8.21 \mathrm{~g} / 100 \mathrm{~g})$ was also observed in the blueberry fruits studied here and was related to the polysaccharide and polymeric compounds present in the fruit peels such as pectic substances, cellulose and lignin.

The total soluble solids content was $12.2^{\circ} \mathrm{Brix}$, similar to that reported by Almenar et al. (2008), who found a value of $12.67^{\circ}$ Brix for highbush blueberries (V. corymbosum L., Elliott). Although the blueberry fruit studied here had a relatively high (TSS) soluble solids content, the TSS/TA ratio was low (7.94). This ratio is an important quality parameter that indicates the relative contributions of sweetness and acidity in the fruit. According to Saftner et al. (2008), blueberries should have TSS values above $10 \%$, total titratable acidity values between $0.3 \%$ and $1.3 \%$, pH values from 2.25 to 4.25 and a TSS/TA ratio between 10 and 33. The blueberries studied here did not present a commercial quality appropriate for in natura consumption in relation to acidity and TSS/TA ratio, and hence their destination for the production of gourmet-type vinegars could be of interest and was explored.

Extraction with acetone ( $80 \% \mathrm{v} / \mathrm{v}$, solution) was more effective in extracting phenolic compounds from the sample, with a content of $1117.84 \mathrm{mg}$ GAE/100 $\mathrm{g}$ (Table 1). When a methanol solution was used in the extraction process, a slightly lower content was found (1004.2 mg GAE/100 g) and ethanol was less effective in extracting phenolic compounds (697.49 mg GAE/100 g) than acetone and methanol. Similar results were found by Jacques et al. (2009) using an ethanolic extract from blueberries (acidified with hydrochloric acid to $\mathrm{pH} 1$ ). These authors found a total phenolic compound content of $816 \mathrm{mg} \mathrm{GAE} / 100 \mathrm{~g}$ and $750.5 \mathrm{mg} \mathrm{GAE} / 100 \mathrm{~g}$ in the Powder Blue and Delite varieties, respectively.

Solvents with different polarity have been used for the extraction of polyphenolic compounds from fruits, such as acidified methanol, ethanol, acidified ethanol, acetone and acidified acetone (CUNHA et al., 2016). As also observed in the present work, Cunha et al. (2016) verified that acetone was $73.1 \%$ more efficient in extracting phenolic compounds ( $1.702 \mathrm{mg} \mathrm{GAE} / 100 \mathrm{~g}$ ) than ethanol (983.4 mg GAE/100 g) in samples of Brazilian blackberries. 
Lower values for total phenolic compounds than those found in the present study were reported by You et al. (2011) and Souza et al. (2014) when using methanol as the extraction solvent. These authors found levels of $338 \mathrm{mg} \mathrm{GAE} / 100 \mathrm{~g}$ (Powder blue organic cultivar) and $305.38 \mathrm{mg} \mathrm{GAE} / 100 \mathrm{~g}$ in blueberry samples grown in Tuskegee, Alabama, USA and in São Paulo, Brazil, respectively. However, it is important to note that the extraction conditions, including the extraction time and temperature and the type of extracting agent, may influence the phenolic compound content determined in the sample.

In relation to the anthocyanin content, acetone also showed a greater extraction capacity $(113.64 \mathrm{mg} / 100 \mathrm{~g})$, followed by methanol $(97.54 \mathrm{mg} / 100 \mathrm{~g})$ and ethanol $(88.29 \mathrm{mg} / 100 \mathrm{~g})$. Acetone extraction was $16.5 \%$ more efficient than methanol and $28.7 \%$ more efficient than ethanol. Similar amounts of total anthocyanins (116 mg/100 g) were found by You et al. (2011) in Tifblue organic cultivar blueberries grown in Tuskegee, USA and Jacques et al. (2009) observed a total anthocyanin content between 72 and $128 \mathrm{mg} / 100 \mathrm{~g}$ in the acid-alcoholic blueberry extracts (acidified ethanol with hydrochloric acid to $\mathrm{pH}$ 1) obtained from the Delite and Powder Blue varieties.

The analytical protocols employed to evaluate the antioxidant capacities of the blueberries used in the present study showed the fruit was rich in antioxidants. In fact, blueberry is considered as one of the greatest sources of antioxidants amongst all fruits and vegetables (REQUE et al., 2014). The blueberry extracts showed high $\mathrm{ABTS}^{*+}$ radical scavenging capacity regardless of the solvent used in the extraction (acetone: $156.06 \mu \mathrm{mol} \mathrm{TE} / \mathrm{g}$, ethanol: $159.42 \mu \mathrm{mol}$ TE/g and methanol: $192.77 \mu \mathrm{mol} \mathrm{TE} / \mathrm{g}$ ). Lower values ( $12.38 \mu \mathrm{mol} \mathrm{TE} / \mathrm{g}$ and $24.45 \mu \mathrm{mol} \mathrm{TE} / \mathrm{g}$ ) were found by Rodrigues et al. (2011) in different cultivars of Brazilian blueberries.

Appreciable DPPH free-radical scavenging ability ( $44.78 \mu \mathrm{mol} \mathrm{TE} / \mathrm{g}$ to $49.93 \mu \mathrm{mol} \mathrm{TE} / \mathrm{g}$ ) was also found in the fruits regardless of the solvent employed. The extraction solvents acetone, ethanol and methanol were shown to have the same ability to extract compounds with DPPH and $\mathrm{ABTS}^{*}+$ radical scavenging potential. Such behaviour can be verified via linearization of the results for antioxidant activity measured by the ABTS and DPPH methods, where a $\left(R^{2}\right)$ coefficient of determination of 0.9978 was found. A smaller DPPH radical scavenging capacity was found by Rodrigues et al. (2011) in blueberries grown in southern Brazil, who described values between $10.14 \mu \mathrm{M} \mathrm{TE} / \mathrm{g}$ (Florida M variety) and $20.55 \mu \mathrm{M} \mathrm{TE} / \mathrm{g}$ (Briteblue variety).

Similar to the behaviour observed for the total phenolic compound and anthocyanin contents, a higher ferric ion-reducing power (FRAP) was observed in the extract obtained with acetone $\left(1357.88 \mu \mathrm{mol} \mathrm{FeSO}_{4} / \mathrm{g}\right)$ and lower values in the methanolic $(1054.85 \mu \mathrm{mol} \mathrm{FeSO} / \mathrm{g})$ and ethanolic $\left(879.09 \mu \mathrm{mol} \mathrm{FeSO}_{4} / \mathrm{g}\right)$ extracts.

\subsection{Wine and vinegars: alcoholic fermentation and acetic oxidation}

The alcoholic fermentation profile of the blueberry based must is shown in Figure 1. The fermentation time was fixed at $125 \mathrm{~h}$, when the release of carbon dioxide stopped and $96.5 \%$ of the total substrate content had already been consumed. Different fermentation times have been reported in the scientific literature for blueberry based musts. Yan et al. (2012) carried out the alcoholic fermentation of mature premier Rabbiteye blueberry juice with the yeast S. cerevisiae AS2.316 for 192 h. López et al. (2016) produced Brigitta cultivar blueberry wine and reported a fermentation time of 35 days at a temperature of $13{ }^{\circ} \mathrm{C}$ using the yeast $S$. cerevisae f. r. bayanus. Different process parameters may affect the performance of an alcoholic fermentation, including the fermentation temperature, substrate concentration and composition, fermentative capacity and alcohol tolerance of the yeast employed in the process (Xavier et al., 2011).

As can be seen in Figure 1, the yeast used in the alcoholic fermentation of blueberry showed high fermentation capacity and alcohol tolerance with an ethanol accumulation of $62.6 \mathrm{~g} / \mathrm{L}$ (corresponding to $7.93 \% \mathrm{v} / \mathrm{v}$ ) after $125 \mathrm{~h}$. The substrate was effectively consumed throughout the fermentation process, with an assimilation greater than $95 \%$ at the end of the process.

Similarly, Yan et al. (2012) reported a final ethanol concentration of $7.63 \%(60.2 \mathrm{~g} / \mathrm{L})$ when fermenting blueberry chaptalized with sucrose ( $\left.15^{\circ} \mathrm{Brix}\right)$. The alcoholic fermentation yield in the present work was $0.43 \mathrm{~g} / \mathrm{g}$ (Table 2), corresponding to a process efficiency of $84 \%$ considering the material balance for the glucose-ethanol conversion by alcoholic fermentation ( $1 \mathrm{~mol}$ of glucose consumed can generate 2 moles of ethanol). Finally, the volumetric productivity in ethanol, corresponding to the ratio between ethanol production and fermentation time, was $0.50 \mathrm{~g} /(\mathrm{L} . \mathrm{h})$.

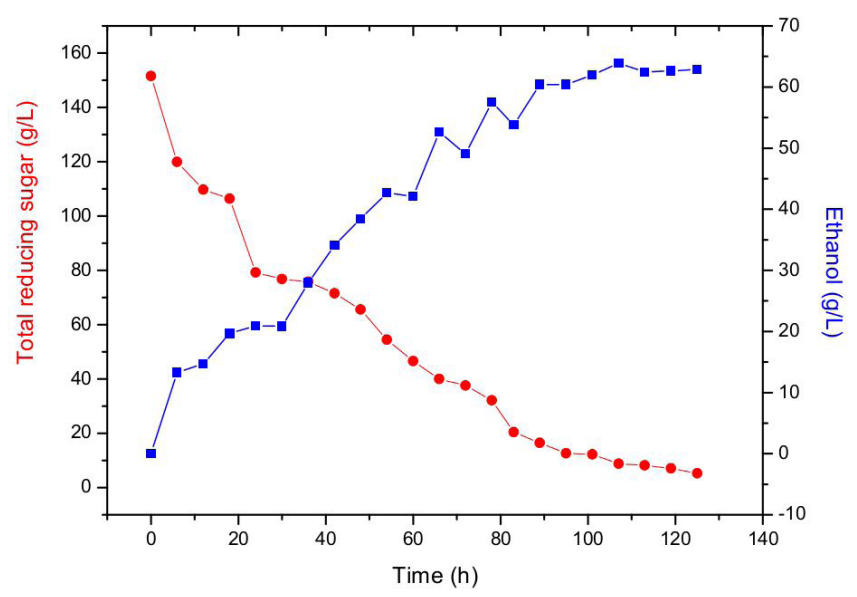

Figure 1. Alcoholic blueberry fermentation profile. 
The acetic acid bacteria isolated from artisanal vinegar demonstrated efficiency in the ethanol-to-acetic acid conversion during three successive fermentation cycles (Figure 2).

The first cycle of acetic acid transformation took $168 \mathrm{~h}$. When the acetic acid concentration reached $4.2 \mathrm{~g} / 100 \mathrm{~mL}$ almost all the ethanol in the blueberry wine had been consumed $(99.7 \%)$, with a yield of $50.09 \%$ in acetic acid and a volumetric productivity of $0.23 \mathrm{~g} /(\mathrm{L} . \mathrm{h})$. At the end of the second and third acetification cycles, acetic acid contents of $4.8 \mathrm{~g} / 100 \mathrm{~mL}$ and $4.2 \mathrm{~g} / 100 \mathrm{~mL}$ were found, respectively.

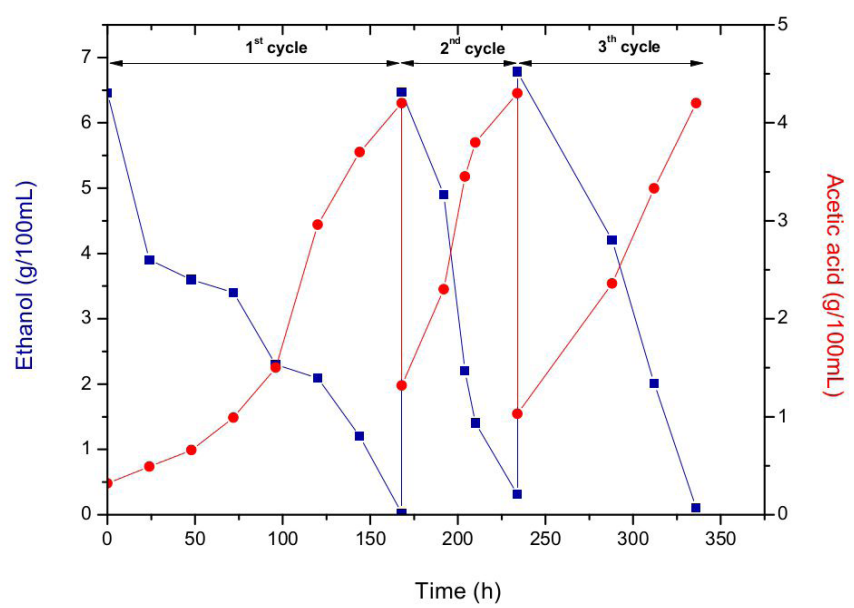

Figure 2. Profile showing the conversion of ethanol to acetic acid by acetic acid bacteria isolated from artisanal vinegar.

Table 2. Fermentative parameters of the sugar-ethanol bioconversion.

\begin{tabular}{lc}
\multicolumn{1}{c}{ Fermentative parameters } & $\begin{array}{c}\text { Values } \\
\text { obtained }\end{array}$ \\
\hline Ethanol production $(\mathrm{P}, \mathrm{g} / \mathrm{L})$ & 62.6 \\
Substrate consumption $(\%)$ & 96.5 \\
Ethanol yield $\left(\mathrm{Y}_{\mathrm{P} / \mathrm{S}}, \mathrm{g} / \mathrm{g}\right)$ & 0.43 \\
Volumetric ethanol productivity $\left(\mathrm{Q}_{\mathrm{P}}, \mathrm{g} /(\mathrm{L} . \mathrm{h})\right.$ & 0.50 \\
Process efficiency $(\mathrm{\eta}, \%)$ & 84.0 \\
\hline
\end{tabular}

According to Brazilian legislation, fruit vinegars must have a minimum volatile acidity of $4.0 \mathrm{~g} / 100 \mathrm{~mL}$ acetic acid and can present a maximum residual ethanol content of $1 \mathrm{~g} / \mathrm{L}$ (BRASIL, 2012). The vinegars obtained here from all the acetification cycles were consistent with the legislation (Table 3). The Brazilian legislation does not establish a maximum value for the content of acetic acid in vinegar, but it is important to point out that vinegar with an acidity exceeding $5.5 \%$ can be rejected by consumers.

There was a reduction in acetification time of $60.7 \%$ in the second cycle (66 h) and an increase in yield (59.76\%) and volumetric productivity $(0.52 \mathrm{~g} /($ L.h $)$ ) in acetic acid, in relation to the first cycle. The reduction in acetification time may be associated with a greater number of acetic acid bacteria inside the acetification barrel, due to the formation of bacterial biofilms. In fact, Cunha et al. (2016) reported that in the second acetic fermentation cycle of blackberry wine, a surface film, known as the mother of vinegar, had already completely formed, and this contributed to a $50 \%$ reduction in acetification time.

Conversely, in the third cycle the acetification time increased to $102 \mathrm{~h}$, with the production of $4.2 \mathrm{~g} / 100 \mathrm{~mL}$ acetic acid, a $98.5 \%$ substrate consumption, and reductions in yield $(48.23 \%)$ and volumetric productivity $(0.40 \mathrm{~g} /(\mathrm{L} . \mathrm{h})$ in terms of acetic acid. The increase in conversion time relative to the second cycle may possibly be due to a greater accumulation of biomass (bacterial biofilm and cells) inside the acetification barrel. Such behaviour was also verified by Cunha et al. (2016), who suggested a probable reduction in the transfer and absorption of oxygen by acetic acid bacteria as a consequence of excess bacterial biomass. The authors pointed out that the availability of oxygen was a limiting factor in the production of vinegar.

The concentrations of phenolic compounds and anthocyanins (Table 3 ) found in the blueberry vinegar produced in the first cycle of acetification were $687.43(\mu \mathrm{g} \mathrm{GAE} / \mathrm{mL})$ and 13.32 ( $\mu \mathrm{g}$ cyanidin-3-glycoside/L), respectively. In subsequent batches, phenolic compound contents of $681.87 \mu \mathrm{g} \mathrm{GAE} / \mathrm{mL}\left(2^{\text {nd }}\right.$ cycle $)$ and 642.98

Table 3. Physicochemical characterization parameters of the blueberry wine and blueberry vinegars.

\begin{tabular}{|c|c|c|c|c|}
\hline \multirow{2}{*}{ Parameters evaluated } & \multirow{2}{*}{ Wine } & \multicolumn{3}{|c|}{ Vinegar } \\
\hline & & $1^{\text {st }}$ cycle & $2^{\text {nd }}$ cycle & $3^{\text {rd }}$ cycle \\
\hline $\mathrm{pH}$ & 3.29 & 2.94 & 2.98 & 2.94 \\
\hline Ethanol (g/L) & $64.5^{\mathrm{a}}$ & $0.02^{b}$ & $0.1^{\mathrm{b}}$ & $0.2^{b}$ \\
\hline Titratable acidity (g/100 g) & 0.43 & 4.2 & 4.8 & 4.2 \\
\hline Total phenolic compounds ( $\mu \mathrm{g} \mathrm{GAE} / \mathrm{mL}$ ) & $706.18^{b}$ & $687.43^{c}$ & $681.87^{d}$ & $842.9^{a}$ \\
\hline Anthocyanins (mg cyanidin-3-glucoside/L) & $197.88^{a}$ & $13.32^{b}$ & $12.8^{b}$ & $15.3^{a, b}$ \\
\hline $\mathrm{ABTS}^{\bullet+*}(\mu \mathrm{mol}$ TE/100 mL) & $356.41 \pm 3.3^{c}$ & $368.39 \pm 1.9^{b}$ & $367.31 \pm 1.9^{b}$ & $402.1 \pm 3.3^{a}$ \\
\hline $\mathrm{DPPH}^{* *}(\mu \mathrm{mol} \mathrm{TE} / 100 \mathrm{~mL})$ & $161.42 \pm 10.7^{c}$ & $186.73 \pm 2.2^{b}$ & $203.60 \pm 13.5^{a, b}$ & $211.3 \pm 3.4^{a}$ \\
\hline $\mathrm{FRAP}^{\#}(\mu \mathrm{mol} \mathrm{FeSO} / 100 \mathrm{~mL})$ & $1419.86 \pm 2.5^{c}$ & $1831.45 \pm 2.2^{\mathrm{a}}$ & $1884.50 \pm 1.3^{d}$ & $1555.3 \pm 2.2^{c}$ \\
\hline
\end{tabular}

a,b,c,d Different letters in the same line are significantly different to each other $(p<0.05)$; GAE: gallic acid equivalent; pH: potential of hydrogen; TE: trolox equivalent; "ABTS"+ and "DPPH: total antioxidant capacity equivalent to Trolox by the "ABTS"+ and "DPPH methods; "FRAP: ferric reducing antioxidant power. 
Blueberry and honey vinegar: successive batch production, antioxidant potential and antimicrobial ability

Fonseca, M. S. et al.

$\mu \mathrm{g} \mathrm{GAE} / \mathrm{mL}\left(3^{\text {th }}\right.$ cycle) and anthocyanin contents of $12.8 \mathrm{mg}$ cyanidin-3-glucoside/L ( $2^{\text {nd }}$ cycle) and $15.39 \mathrm{mg}$ cyanidin-3-glucoside/L ( $3^{\text {rd }}$ cycle), were observed. A somewhat higher concentration of phenolic compounds (981 $\mu \mathrm{g}$ GAE/mL) was observed by Kim et al. (2012) when evaluating a sample of blueberries vinegar.

A slight reduction in the total phenolic compounds content found in the wine $(706.18 \mu \mathrm{g} \mathrm{GAE} / \mathrm{mL}$, Table 3) was noted in the vinegars produced from them, which may have been due to oxidation of phenolic compounds during transformation of the alcohol into acetic acid. A reduction in the anthocyanin content was also found in the vinegars produced.

According to Hornedo-Ortega et al. (2017), the sensitive nature of anthocyanins is affected by food processing techniques such as fermentation, which alters both their chemical composition and sensory properties. These researchers evaluated the impact of the alcoholic and acetic fermentation processes on individual anthocyanin compounds in strawberry wine and vinegar, and reported that alcoholic fermentation moderately affected the anthocyanin compounds (19\% decrease), but that the acetic fermentation process produced higher losses ( $91 \%$ of the anthocyanin composition).

Although several studies in the scientific literature have described the antioxidant potential of different fruits, there are few reports on the antioxidant capacity of fruit vinegars (CUNHA et al., 2016). The results of the in vitro antioxidant activity assays (Tables 2 and 3) showed that both the in natura blueberry fruit, and the wine and vinegars produced from them, presented high antioxidant capacity. The blueberry vinegars showed significant radical scavenging ability against ABTS•+ (368.39 to $402.15 \mu \mathrm{mol}$ TE/100 mL) and DPPH (186.73 to $211.39 \mu \mathrm{mol}$ TE/100 mL) and also ferric ion-reducing ability (1881.45 to $1884.5 \mu \mathrm{mol} \mathrm{FeSO}_{4} / 100 \mathrm{~mL}$ ).

Another important aspect to note is that the acetification process led to a small increase in the antioxidant capacity of the vinegars in relation to the wine (Table 3), although the total phenolic compound content of the vinegars was somewhat lower than that of the original wine. Such behaviour can be justified by the production of acetic acid, which has antioxidant potential due to its ability to donate hydrogen protons $\left[\mathrm{H}^{+}\right]$.

\subsection{Determination of the antimicrobial activity of blueberry vinegar using the zone of inhibition method}

Vinegars of different origins have been reported in the literature as being effective antimicrobial agents against different microorganisms (PRIYADARSHINI et al., 2014; CASTRO et al., 2015; PARK et al., 2016), and this behaviour was also found in the present study. Figure 3 and Table 4 show that the blueberry vinegars presented inhibitory effects towards Salmonella enterica serovar Typhimurium (Gram negative bacterium) and Bacillus subtilis (Gram positive bacterium). An inhibitory effect of such microorganisms was observed, with inhibition zones of between 9.3 and $9.6 \mathrm{~mm}^{-1}$ when vinegars with acetic acid concentrations between $4.2 \%$ ( $1^{\text {st }}$ and $3^{\text {th }}$ cycle) and $4.8 \%\left(2^{\text {nd }}\right.$ cycle) were used. Lower antimicrobial activity towards $S$. enterica Typhimurium was reported by Priyadarshini et al. (2014) in a study with sweet lime fruit vinegar, reporting an inhibition zone of $6 \mathrm{~mm}$. On the other hand, in the present study the growth of E. coli and $S$. aureus was not affected by any of the vinegar samples evaluated, and fungicidal activity against Candida albicans and $C$. tropicalis was also not found.

Bakir et al. (2017) found antibacterial activity against Staphylococcus aureus, Salmonella enterica Typhimurium, and Escherichia coli in blueberry vinegar, with inhibition zones of 9, 10 and $10 \mathrm{~mm}$, respectively. An antibacterial effect against Salmonella enterica Typhimurium was also verified, and the authors emphasized that the antioxidant compounds and the acidity of the vinegar were responsible for the antibacterial action. Similarly, Cherif et al. (2014) verified a strong antimicrobial effect against Staphylococcus aureus, Pseudomonas aeruginosa and Candida albicans by date vinegar produced in the region of Ghardaïa in Algeria. Kelebek et al. (2017) reported a greater antimicrobial effect of grape vinegars against Staphylococcus aureus ATCC 29213, E. coli ATCC 25922 and Pseudomonas aeruginosa ATCC 27853 when compared to apple vinegars. According to the authors, the greater antimicrobial potential of grape vinegars was correlated with their higher antioxidant capacity.

Table 4. Antimicrobial activity of blueberry vinegars.

\begin{tabular}{|c|c|c|c|c|c|}
\hline \multirow{2}{*}{ Microbial strains } & \multicolumn{5}{|c|}{ Inhibition zone $\left(\mathrm{mm}^{-1}\right)$} \\
\hline & $1^{\text {st }}$ cycle & $2^{\text {nd }}$ cycle & $3^{\text {rd }}$ cycle & Tetracycline & Fluconazole \\
\hline E. coli ATCC 25922 & * & * & * & $22.0 \pm 0.25$ & * \\
\hline S. enterica Typhimurium ATCC 0028 & $9.3 \pm 0.05$ & $9.6 \pm 0.11$ & $9.6 \pm 0.05$ & $20.0 \pm 0.08$ & * \\
\hline B. subtilis ATCC 19659 & $9.6 \pm 0.01$ & $9.3 \pm 0.05$ & $9.3 \pm 0.25$ & $31.0 \pm 0.34$ & * \\
\hline S. aureus ATCC 25923 & * & * & * & $23.0 \pm 0.35$ & * \\
\hline C. albicans ATCC 118804 & * & * & * & * & $22.0 \pm 0.08$ \\
\hline C. tropicalis ATCC 13803 & * & * & * & * & $29.0 \pm 0.10$ \\
\hline
\end{tabular}

Tetracycline: standard bactericidal molecule, Fluconazole: standard fungicidal molecule; *: no inhibition at the concentration evaluated 


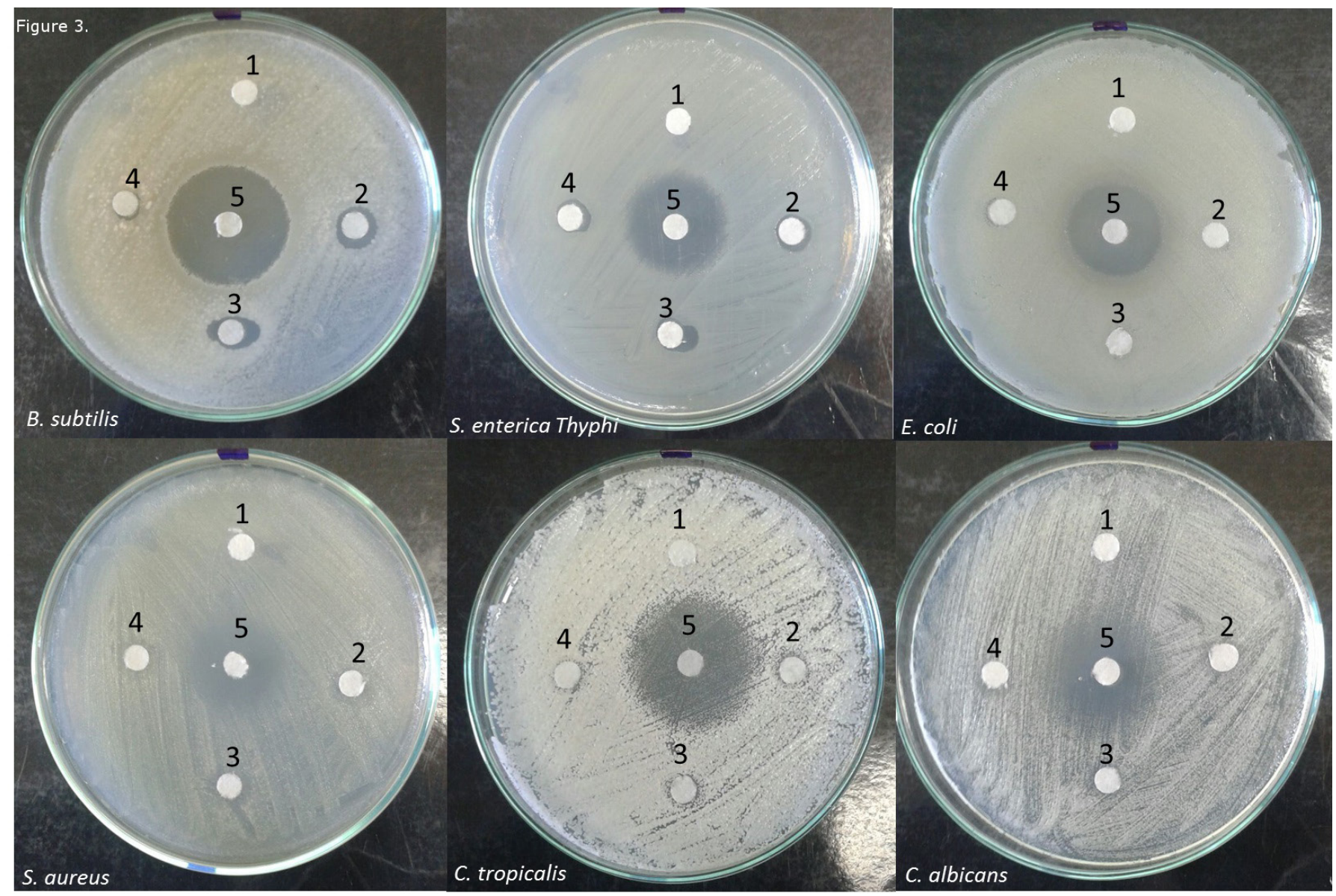

Figure 3. Diameters of the Inhibition zones against different microorganisms for blueberry vinegar produced in the $3^{\text {rd }}$ acetification cycle (2, 3 and 4) at a concentration of 4.2\%. 1: peptone water as the negative control and 5: tetracycline for bacteria and fluconazole for yeast as the positive control.

\section{Conclusions}

The blueberry fruits produced in the southwestern region of the state of Paraná, Brazil and studied in this work presented high contents of total phenolic compounds and anthocyanins and a high antioxidant potential. Acetone showed a greater capacity to extract the phenolic compounds and anthocyanins from the fruit samples. High total soluble solids contents were found in the fruits, but few acids and a low TSS/TA ratio. They were therefore of greater interest for vinegar production than for in natura consumption.

Blueberry wine and vinegars with added honey were produced, and presented appreciable total phenolic compound contents and high antioxidant capacity. The vinegars obtained in three successive acetification cycles showed an antioxidant potential slightly higher than that of the wine produced using blueberries and used as the raw material. In addition, the vinegars showed antimicrobial potential against Bacillus subtilis and Salmonella enterica. The production of blueberry with honey vinegars by the slow process carried out in wooden barrels could be an attractive option for adding value and strengthening the blueberry (and honey) production chains of small farms in southern Brazil.

\section{Acknowledgements}

The authors are grateful to the Coordenação de Aperfeiçoamento de Pessoal de Nível Superior (CAPES), Conselho Nacional de Desenvolvimento Científico e Tecnológico (CNPq), and Fundação Araucária (Brazil; M.A.A. Cunha) for their financial support.

\section{References}

ALMENAR, E.; SAMSUDIN, H.; AURAS, R.; HARTE, B.; RUBINO, M. Postharvest shelf life extension of blueberries using a biodegradable package. Food Chemistry, v. 110, n. 1, p. 120-127, 2008. http:// dx.doi.org/10.1016/j.foodchem.2008.01.066. PMid:26050174.

BAKIR, S.; DEVECIOGLU, D.; KAYACAN, S.; TOYDEMIR, G.; KARBANCIOGLU-GULER, F.; CAPANOGLU, E. Investigating the antioxidant and antimicrobial activities of different vinegars.

European Food Research and Technology, v. 243, n. 12, p. 2083-2094, 2017. http://dx.doi.org/10.1007/s00217-017-2908-0. 
Blueberry and honey vinegar: successive batch production, antioxidant potential and antimicrobial ability Fonseca, M. S. et al.

BRAND-WILLLIAMS, W.; CUVELIER, M. E.; BERSET, C. Use of a free radical method to evaluate antioxidant activity. LebensmittelWissenschaft \& Technologie - LWT, v. 28, n. 1, p. 25-30, 1995. https://doi.org/10.1016/S0023-6438(95)80008-5.

BRASIL. Ministério da Agricultura, Pecuária e Abastecimento. Instrução Normativa $n^{\circ}$ 6, de 03 de abril de 2012. Estabelece os padrões de identidade e qualidade e a classificação dos fermentados acéticos. Diário Oficial [da] República Federativa do Brasil, Brasília, DF, 2012.

BUDAK, N. H.; AYKIN, E.; SEYDIM, A. C.; GREENE, A. K.; GUZEL-SEYDIM, Z. B. Functional properties of vinegar. Journal of Food Science, v. 79, n. 5, p. R757-764, 2014. http://dx. doi. org/10.1111/1750-3841.12434. PMid:24811350.

BUDAK, N. H.; GUZEL-SEYDIM, Z. B. Antioxidant activity and phenolic content of wine vinegars produced by two different techniques. Journal of the Science of Food and Agriculture, v. 90 , n. 12, p. 2021-2026, 2010. http://dx.doi.org/10.1002/ jsfa.4047. PMid:20589746.

CASTRO, R. D.; MOTA, A. C. L. G.; LIMA, E. O.; BATISTA, A. U. D.; OLIVEIRA, J. A.; CAVALCANTI, A. L. Use of alcohol vinegar in the inhibition of Candida spp. and its effect on the physical properties of acrylic resins. BMC Oral Health, v. 15, n. 52, p. 1-7, 2015. http://dx.doi.org/10.1186/s12903-015-0035-5. PMid:25928798.

CHERIF, B.; BOURAS, N.; OUMOUNA, M.; OULD EL HADJ, M. D.; HOLTZ, M. D.; SABAOU, N. Ethno-pharmacological use and antimicrobial activity of traditional date vinegar of Ghardaïa. Algerian Journal of Arid Environment, v. 4, n. 1, p. 83-93, 2014. http://dx.doi.org/10.12816/0008914.

CLINICAL AND LABORATORY STANDARDS INSTITUTE - CLSI. Methods for dilution antimicrobial susceptibility tests for bacteria that grow aerobically. M7-A6 Wayne. Pennsylvania: CLSI, 2003.

CLINICAL AND LABORATORY STANDARDS INSTITUTE - CLSI. Reference method for broth dilution antifungal susceptibility testing of yeasts. M27-A3 Wayne. Pennsylvania: CLSI, 2008.

COLAK, N.; TORUN, H.; GRUZ, J.; STRNAD, M.; SUBRTOVA, M.; INCEER, H.; AYAZ, F. A. Comparison of phenolics and phenolic acid profiles in conjunction with Oxygen Radical Absorbing Capacity (ORAC) in berries of Vaccinium arctostaphylos $L$. and V. myrtillus L. Polish Journal of Food and Nutrition Sciences, v. 66, n. 2, p. 85-91, 2016. http://dx. doi.org/10.1515/pjfns-2015-0053.

CUNHA, M. A.; LIMA, K. P.; SANTOS, V. A. Q.; HEINZ, O. L.; SCHIMIDT, C. A. P. Blackberry vinegar produced by successive acetification cycles: production, characterization and bioactivity parameters. Brazilian Archives of Biology and Technology, v. 59, n. 1, p. 1-10, 2016. http://dx.doi.org/10.1590/1678-43242016150136.

DIACONEASA, Z.; LEOPOLD, L.; RUGINA, D.; AYVAZ, H.; SOCACIU, C. Antiproliferative and antioxidant properties of anthocyanin rich extracts from blueberry and blackcurrant juice. International Journal of Molecular Sciences, v. 16, p. 23522365, 2015. https://doi.org/10.3390/ijms16022352.

FOOD AND AGRICULTURE ORGANIZATION OF THE UNITED NATIONS - FAO. Statistics: crops production quantity of blueberry by Canada and United States in 2014. Roma: FAO, 2014. Available at: <http://www.fao.org/faostat/en/\#data/QC>. Accessed on: 7 mar. 2017.

GIBSON, L.; RUPASINGHE, H. P.; FORNEY, C. F.; EATON, L. Characterization of changes in polyphenols, antioxidant capacity and physico-chemical parameters during lowbush blueberry fruit ripening. Antioxidants, v. 2, n. 4, p. 216-229, 2013. http:// dx.doi.org/10.3390/antiox2040216. PMid:26784460.

HO, C. W.; LAZIM, A. M.; ZAKI, U. K. H. H.; LIM, S. J. Varieties, production, composition and health benefits of vinegars: a review. Food Chemistry, v. 221, p. 1621-1630, 2016. https:// doi.org/10.1016/j.foodchem.2016.10.128.

HORNEDO-ORTEGA, R.; ÁLVAREZ-FERNÁNDEZ, M. A.; CEREZO, A. B.; GARCIA-GARCIA, I.; TRONCOSO, A. M.; GARCIA-PARRILLA, M. C. Influence of fermentation process on the anthocyanin composition of wine and vinegar elaborated from strawberry. Journal of Food Science, v. 82, n. 2, p. 364-372, 2017. https:// doi.org/10.1111/1750-3841.13624.

HORWITZ, W. Official methods of analysis of the Association of Official Analytical Chemists. 20th ed. Gaithersburg: AOAC, 2016. v. 1, p. 10.

JACQUES, A. C.; PERTUZATTI, P. B.; BARCIA, M. T.; ZAMBIAZI, R. C. Nota científica: compostos bioativos em pequenas frutas cultivadas na região sul do Estado do Rio Grande do Sul. Brazilian Journal of Food Technology, v. 12, n. 2, p. 123-127, 2009. http://dx.doi.org/10.4260/BJFT20094608.

KELEBEK, H.; KADIROĞLU, P.; DEMIRCAN, N. B.; SELLI, $S$. Screening of bioactive components in grape and apple vinegars: antioxidant and antimicrobial potential. Journal of the Institute of Brewing, v. 123, n. 3, p. 407-416, 2017. http:// dx.doi.org/10.1002/jib.432.

KIM, S. H.; CHO, H. K.; SHIN, H. S. Physicochemical properties and antioxidant activities of commercial vinegar drinks in Korea. Food Science and Biotechnology, v. 21, n. 6, p. 1729-1734, 2012. http://dx.doi.org/10.1007/s10068-012-0230-y.

LÓPEZ, N. E. L.; LEIVA, V. U.; CARRASCO, C. A. Development of a distilled-like alcoholic drink from blueberry (Vaccinium corymbosum) cv. Brigitta, and sensory analysis. Acta Agronómica, v. 65, n. 1, p. 1-8, 2016. http://dx.doi.org/10.15446/acag.v65n1.43862.

MILLER, G. L. Use of dinitrosalicylic acid reagent for determination of reducing sugar. Analytical Chemistry, v. 31, n. 3, p. 426-428, 1959. http://dx.doi.org/10.1021/ac60147a030.

PARK, S. Y.; KANG, S.; HA, S. D. Antimicrobial effects of vinegar against norovirus and Escherichia coli in the traditional Korean vinegared green laver (Enteromorpha intestinalis) salad 
Blueberry and honey vinegar: successive batch production, antioxidant potential and antimicrobial ability Fonseca, M. S. et al.

during refrigerated storage. International Journal of Food Microbiology, v. 238, p. 208-214, 2016. https://doi.org/10.1016/j. ijfoodmicro.2016.09.002

PRIYADARSHINI, S.; JOHN, S.; IYER, P. Antimicrobial activity and characterisation of microflora of vinegar preparations developed from peels and fruit of sweet lime. European Journal of Biotechnology and Bioscience, v. 2, n. 2, p. 42-45, 2014.

REQUE, P. M.; STEFFENS, R. S.; SILVA, A. M. D.; JABLONSKI, A.; FLÔRES, S. H.; RIOS, A. D. O.; JONG, E. V. D. Characterization of blueberry fruits (Vaccinium spp.) and derived products. Food Science and Technology, v. 34, n. 4, p. 773-779, 2014. http:// dx.doi.org/10.1590/1678-457X.6470.

RODRIGUES, E.; POERNER, N.; ROCKENBACH, I. I.; GONZAGA, L. V.; MENDES, C. R.; FETT, R. Phenolic compounds and antioxidant activity of blueberry cultivars grown in Brazil. Food Science and Technology, v. 31, n. 4, p. 911-917, 2011. http:// dx.doi.org/10.1590/S0101-20612011000400013.

RUFINO, M. S.M.; ALVES, R. E.; BRITO, E. S. D.; PÉREZ-JIMÉNEZ, J.; SAURA-CALIXTO, F.; MANCINI-FILHO, J. Bioactive compounds and antioxidant capacities of 18 non-traditional tropical fruits from Brazil. Food Chemistry, v. 121, n. 4, p. 996-1002, 2010. http://dx.doi.org/10.1016/j.foodchem.2010.01.037.

SAFTNER, R.; POLASHOCKB, J.; EHLENFELDTB, M.; VINYARDC, B. Instrumental and sensory quality characteristics of blueberry fruit from twelve cultivars. Postharvest Biology and Technology, v. 49, p. 19-26, 2008. http://dx.doi.org/10.1016/j. postharvbio.2008.01.008.

SHI, M.; LOFTUS, H.; MCAINCH, A. J.; SU, X. Q. Blueberry as a source of bioactive compounds for the treatment of obesity, type 2 diabetes and chronic inflammation. Journal of Functional Foods, v. 30, p. 16-29, 2017. https://doi.org/10.1016/j.jff.2016.12.036.

SINGLETON, V. L.; ORTHOFER, R.; LAMUELA-RAVENTÓS, R. $M$. Analysis of total phenols and other oxidation substrates and antioxidants by means of folin-ciocalteu reagent. Methods in Enzymology, v. 299, p. 152-178, 1999. https://doi.org/10.1016/ S0076-6879(99)99017-1.

SOUZA, V. R.; PEREIRA, P. A. P.; SILVA, T. L.; OLIVEIRA LIMA, L. C.; PIO, R.; QUEIROZ, F. Determination of the bioactive compounds, antioxidant activity and chemical composition of
Brazilian blackberry, red raspberry, strawberry, blueberry and sweet cherry fruits. Food Chemistry, v. 156, p. 362-368, 2014. http://dx.doi. org/10.1016/j.foodchem.2014.01.125.

TRCEK, J.; MAHNIC, A.; RUPNIK, M. Diversity of the microbiota involved in wine and organic apple cider submerged vinegar production as revealed by DHPLC analysis and next-generation sequencing. International Journal of Food Microbiology, v. 223, p. 57-62, 2016. https://doi.org/10.1016/j.ijfoodmicro.2016.02.007.

UNITED STATES DEPARTMENT OF AGRICULTURE - USDA. Agricultural Research Service - National Nutrient Database for Standard Reference. USA: USDA, 2016. Blueberries, canned, heavy syrup, solids and liquids (Basic Report 09052). Available at: <https://ndb.nal.usda.gov/ndb/foods/show/2167?fgcd=\&man $\mathrm{u}=\&$ format=Abridged \&offset=\&sort=ndb\&order=asc\&ds=Stand $\operatorname{ard}+$ Reference $\& \mathrm{q}=\& q p=\& q a=\& q n=\& q=\& i n g=>$. Accessed on: 7 mar. 2017

WANG, H.; GUO, X.; HU, X.; LI, T.; FU, X.; LIU, R. H. Comparison of phytochemical profiles, antioxidant and cellular antioxidant activities of different varieties of blueberry (Vaccinium spp.). Food Chemistry, v. 217, p. 773-781, 2017. https://doi.org/10.1016/j. foodchem.2016.09.002.

WANG, W. D.; XU, S. Y. Degradation kinetics of anthocyanins in blackberry juice and concentrate. Journal of Food Engineering, v. 82 , n. 3, p. 271-275, 2007. http://dx.doi.org/10.1016/j. jfoodeng.2007.01.018.

XAVIER, D.; IVANOV, R. C.; CUNHA, M. A. A.; PEREIRA, E. A. Produção e caracterização de vinagre de fisalis. Revista Brasileira de Pesquisa em Alimentos, v. 2, n. 1, p. 27-32, 2011. http://dx.doi.org/10.14685/rebrapa.v2i1.18.

YAN, H. G.; ZHANG, W. H.; CHEN, J. H.; DING, Z. E. Optimization of the alcoholic fermentation of blueberry juice by AS 2.316 Saccharomyces cerevisiae wine yeast. African Journal of Biotechnology, v. 11, n. 15, p. 3623-3630, 2012. http://dx.doi. org/10.5897/AJB11.3635.

YOU, Q.; WANG, B.; CHEN, F.; HUANG, Z.; WANG, X.; LUO, P. $G$. Comparison of anthocyanins and phenolics in organically and conventionally grown blueberries in selected cultivars. Food Chemistry, v. 125, n. 1, p. 201-208, 2011. http://dx.doi. org/10.1016/j.foodchem.2010.08.063. PMid:26434281. 